\title{
Nipa (Nypa fruticans Wurmb) Sap Collection in Southern Thailand I. Sap Production and Farm Management
}

\author{
Naohiro Matsui $^{1}$, Yasuyuki Okimori ${ }^{2}$, Fumio Takahashi ${ }^{1}$, Koji Matsumura ${ }^{3} \&$ Noparat Bamroongrugsa $^{4}$ \\ ${ }^{1}$ Environment Department, The General Environmental Technos Co., Ltd., Osaka, Japan \\ ${ }^{2}$ Business Department, The General Environmental Technos Co., Ltd., Osaka, Japan \\ ${ }^{3}$ Power Engineering R\&D Center, The Kansai Electric Power Co., Inc., Kyoto, Japan \\ ${ }^{4}$ Faculty of Environment Management, Princes of Songkla University, Hat Yai, Thailand \\ Correspondence: Naohiro Matsui, Environment Department, The General Environmental Technos Co., Ltd., 1-3-5 \\ Azuchimachi, Chuo-ku, Osaka 541-0052, Japan. Tel: 81-662-637-314. E-mail: matui_naohiro@kanso.co.jp
}

\author{
Received: July 30, 2014 Accepted: August 15, 2014 Online Published: September 9, 2014 \\ doi:10.5539/enrr.v4n4p75 URL: http://dx.doi.org/10.5539/enrr.v4n4p75
}

\begin{abstract}
Nipa (Nypa fruticans Wurmb) sap/sugar production has been practiced sustainably over a hundred years in southern Thailand. Farming techniques such as tapping were established over the times, however the variation of sap/sugar production and its regulating factors are not yet fully recognized. The daily sap yield and the sugar content were monitored for three years (2010,2011 and 2012) in 7 nipa farms. The daily sap yield varied from 0.02 to 2 litres per fruit stalk with the sugar content ranging from 10.6 to $28.6 \%$. The duration of sap production from the same fruit stalk was from 20 days to 56 days and the mean sugar content of 1,892 measurements was $18.1 \%$. Although the density of the fruit stalks was of minimal significance, the growths of the fruit stalk were significantly related to sap production. Thicker and longer fruit stalk produced more sap. Water inundation affected the growths of the fruit stalk resulting in a decrease in sugar production 4 to 5 months after the rainy season. Nipa farms in the study site produced sugar at the rates of 3.2 to 6.5 tons/ha/year nevertheless farm management to increase growths of fruit stalk and to reduce impact of water inundation could enhance nipa sap/sugar production.
\end{abstract}

Keywords: nipa, sap/sugar production, fruit stalk, mangrove

\section{Introduction}

Nipa (Nypa fruticans Wurmb) is a useful mangrove species in South, Southeast Asia and Oceania. Many palm species including nipa have been tapped throughout the tropical region for the production of fresh juice, fermented drinks, syrup, and raw and refined sugar (Dransfield, 1977; Päivöke, 1985; Udofia et al., 2005). Such a practice has a long history, for example sugars of Borassus flabellifer were already extracted by Hindus 4,000 years ago (Fox, 1977). Besides its traditional uses, nipa sap is currently the focus of attention as a feedstock for bioethanol (Matsui et al., 2011; Tsuji et al., 2011; Tamunaidu et al., 2013) on the basis of the finding that nipa could produce a higher amount of bioethanol than sugarcane and cassava at a lower cost (Hamilton \& Murphy, 1988). Despite its usefulness, there is still limited scientific data on nipa compared with other useful tropical palms such as coconut and oil palm. In particular, studies on nipa sap have been scarce since the monumental scientific reviews of nipa sap were published (Hamilton \& Murphy, 1988; Päivöke, 1983). These studies had significant implication since they showed actual amount of sap production from some fruit stalks (which are also called flower stalks or inflorescence). Upon these findings, it would be necessary to accumulate more information about sap production and/or growth behavior of fruit stalks, in order to promote nipa farming in places where coastal development is needed.

Over the past 50 years, approximately one-third of the world's mangrove forests have been lost due to anthropogenic activities (Alongi, 2002). Considering the current alarming rate of mangrove forest destruction, coastal land management including nipa farming would be an effective countermeasure against irrational exploitation of degraded coastal areas. As for the planting technique for nipa, a number of trials were conducted in the sourthern Thailand (Bamrrongrugsa \& Purintavarakul, 2006; Bamrrongrugsa et al., 2008). This study aims 
at examining the management of nipa farms and sap/sugar production at actual nipa farms to elucidate the potential of nipa farming as promising land use in tropical coastal areas.

We firstly examined the actual management of nipa farms and sap/sugar production in part I of our study and followed it up with the examination of factors controlling nipa sap production from the viewpoint of biomass and soil properties in part II.

\section{Methods}

\subsection{Study Site}

This study was conducted at Pak Phanang Basin in Nakorn Si Thammarat Province in southern Thailand (Figure 1). Pak Phanang is an area of approximately 304,000 ha, of which 3,200 ha or about $10 \%$ are natural nipa palm forest (Bamroongrugsa et al., 2004). Nipa in Thailand can be found elsewhere apart from this study site, in the central Thailand and the eastern and Indian Ocean sides of Thailand. However, active sugar production from nipa sap as a family-run business remains only in this study site, wherein nipa has been tapped at least since one hundred years ago. Farmers in this basin earn their income mostly from nipa sugar production. As of May 2005, about 4,850 farmers, which is $60-70 \%$ of the total population in the area, are engaged in nipa sugar production.

The climate of the study site is characterized by uniform high temperatures from 24 to $32{ }^{\circ} \mathrm{C}$ with the rainfall varying between 1,900 and 2,400 $\mathrm{mm}$ (Figure 2). Rainfall concentrates on certain months between October and January. The study site received a record rainfall of $971 \mathrm{~mm}$ in November 2011.
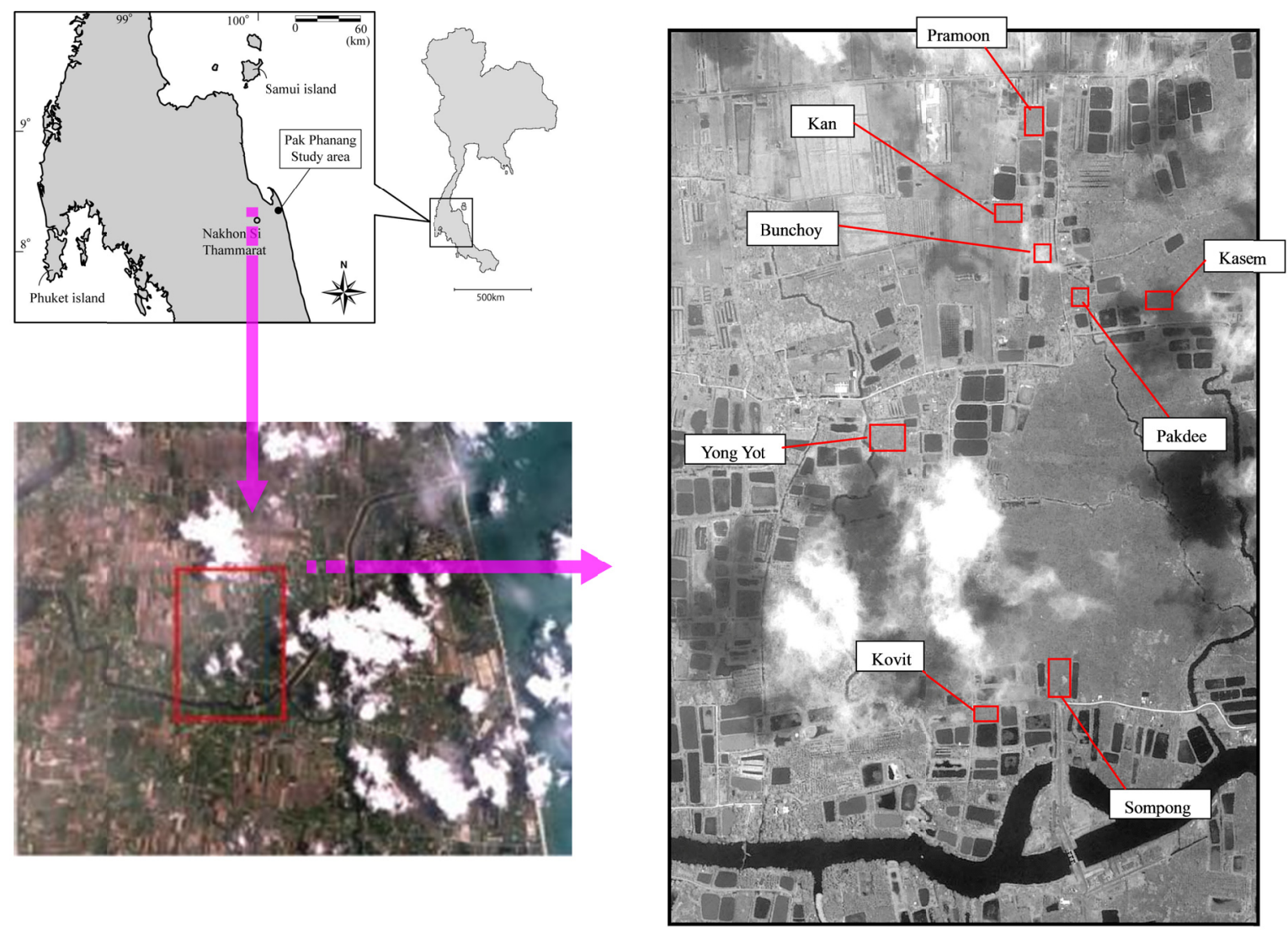

Figure 1. Locations of nipa farms where this study was conducted. The lower left panel is the color image of THEOS panchromatic satellite with a $15 \mathrm{~m}$ spatial resolution showing the locations of nipa farms indicated in green. The lower right panel is the black and white image of THEOS panchromatic satellite with a $2 \mathrm{~m}$ spatial resolution. Rectangular areas in the image of right panel are shrimp ponds 


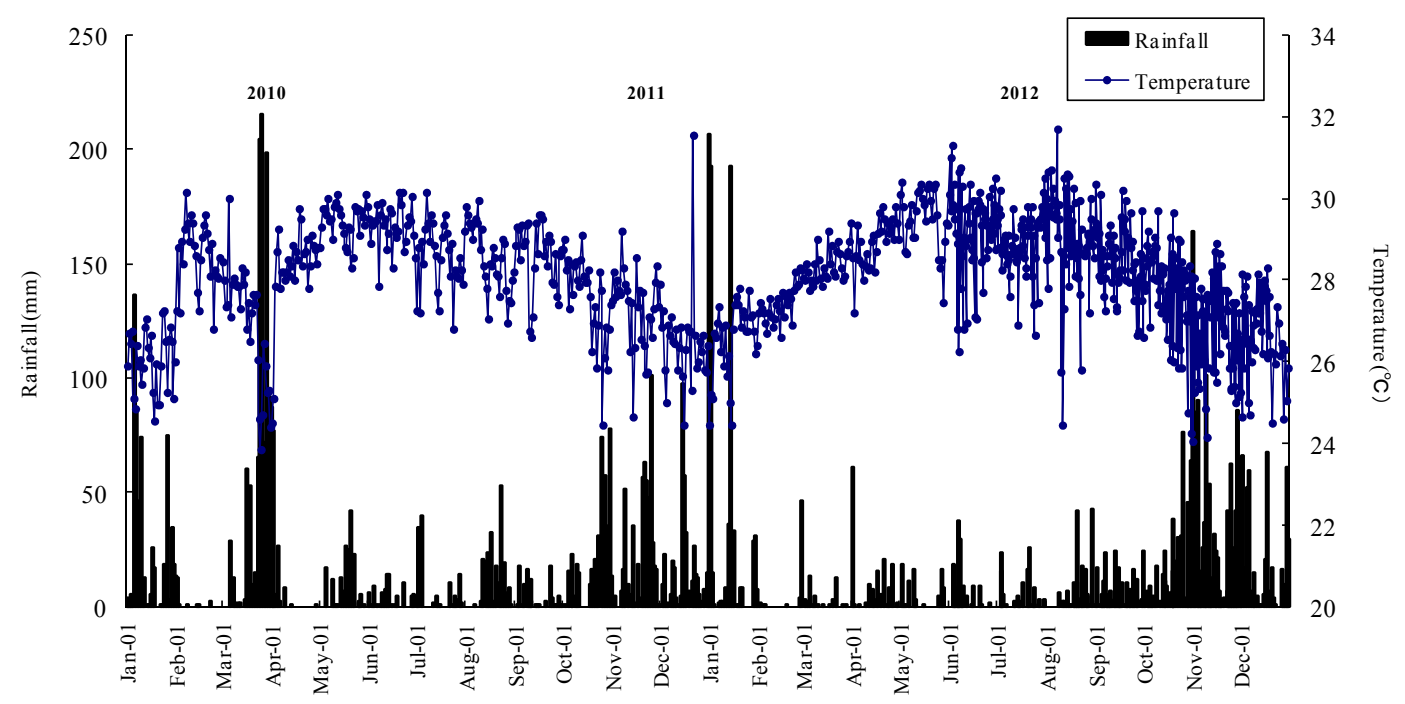

Figure 2. Daily rainfall and temperature in three consecutive years (2010, 2011 and 2012). A high amount of rainfall is concentrated from November to January whereas there is a small amount of rainfall from May to

September

\subsection{Farm Operation}

In order to understand the general conditions in nipa farm operation, we firstly surveyed seven farmers and collected information regarding age, area of plantation, number of fruit stalks under sap collection and former land use. The yearly schedule of sap collection was also gathered for each farm.

\subsection{Sap Production and Sugar Content Monitoring}

At the nipa plantation sites, 3 or 4 sap producing fruit stalks were selected at each of five farms to monitor sap production. Sap was collected every morning between July 2010 and December 2012 and its volume and sugar content (Brix \% w/w) were measured using a refractometer (Kyoto Electronics Manufacturing Co., Ltd., Japan). Sap monitoring was started when the farmer initiated sap collection and was ended when the farmer stopped collecting. The duration of sap collection was quite variable from less than 10 days to over 60 days. When the monitoring of one fruit stalk was finished, we moved to another to continue sap monitoring.

At one of the farms, the locations of bamboo containers allocated for sap collection were identified using a handy Global Positioning System (GPS) (Garmin eTrex 20) three times in June, September and December 2012.

Because daily sap monitoring only demonstrates the sap productivity of a single fruit stalk, sugar production was monitored at five farms between June 2012 and May 2013 in order to determine sap productivity on the farm (area) basis.

\subsection{Growth of Fruit Stalks}

Because sap is produced from the fruit stalk, understanding the growth behavior of the fruit stalk is highly important. Permanent plots with a size of $400 \mathrm{~m}^{2}$ were established for studying the status of nipa fruit stalks. Two times a year in June and December, the number of fruit stalks according to different growth stages was counted at four farms. Growth stage was classified into four categories, 1) fruit bud emergence stage, 2) development stage of the fruit stalk, 3) flowering and fruiting, and 4) fruit maturation (Figure 9).

For fruit stalks from which sap was collected, the length and diameter of fruit stalks as well as the number of surrounding fronds around fruit stalks were measured at three farms. To determine the photosynthetic activity of surrounding fronds, chlorophyll content was measured using a chlorophyll meter (SPAD-501, Minolta Co., Ltd., Japan).

The growth rate of fruit stalks was also monitored. Growth of fruit stalks was monitored at three farms from 17 July to 30 September for 75 days. One life cycle of a fruit stalk in one year, that is, starting from the emergence of the flower bud until the detachment of ripe nuts, was studied for fruit stalks under a high and low influence of the water in one farm. 


\section{Results}

\subsection{Nipa Farming Operation}

Five nipa farms studied were either shrimp ponds or paddies previously while the former land use of three farms were not identified (Table 1). Three farms (Yong Yot's, Sompong's and Bunchoy's) have been operated over 100 years since their establishment, showing the longevity of nipa farming. Nipa farming has been normally operated by $2-3$ members of a family, but a small farm (Pramoon's) has been managed by only one person. On average, $150-200$ fruit stalks are tapped for daily sap collection and this number seems to be manageable for two persons to work in a day.

Table 1. Site conditions of the studied nipa farms

\begin{tabular}{lrrrrr}
\hline Farmer name & $\begin{array}{c}\text { Age of plantation } \\
\text { (as of 2014) }\end{array}$ & Farm area $\left(\mathrm{m}^{2}\right)$ & $\begin{array}{c}\text { Number of flower stalks Number of remaining } \\
\text { for sap collection }\end{array}$ & Former land use \\
stalks & & S \\
Kovit* & 14 & 4,800 & $90-150$ & 200 & Shrimp pond \\
Pakdee & 48 & 12,800 & $100-300$ & $5-5$ & Paddy \\
Yong Yot* & $>100$ & 14,400 & 180 & $5-10$ & Unknown \\
Kan* & 7 & 12,800 & $120-160$ & $5-7$ & Paddy \\
Kasem & 34 & 18,381 & $60-80$ & 4 & Shrimp pond \\
Pramoon & 33 & 5,830 & 150 & 5 & Paddy \\
Sompong* & $>100$ & 17,600 & 150 & $5-6$ & Unknown \\
Bunchoy** & $>100$ & 16,000 & & Unknown \\
\hline
\end{tabular}

* -part I \& II, ** -part II only.

Sap was collected almost all year around at two farms (Kan's and Sompong's) (Table 2); however, at certain times of a year, the other famers had to stop sap collection owing to the insufficient number of workers and to water inundation during the rainy season. Considering that 2 persons were engaged in nipa farming in a $1-1.5$ ha farm, the working area for one person was approximately $0.5-0.75$ ha.

Table 2. Schedule of sap collection

\begin{tabular}{|c|c|c|c|c|c|c|c|c|c|c|c|c|}
\hline Farmer's name & Jun & Jul & Aug & Sep & Oct & Nov & Dec & Jan & Feb & Mar & Apr & May \\
\hline \multicolumn{13}{|l|}{ Kovit } \\
\hline \multicolumn{13}{|l|}{ Pakdee } \\
\hline \multicolumn{13}{|l|}{ Yong Yot } \\
\hline \multicolumn{13}{|l|}{ Kan } \\
\hline \multicolumn{13}{|l|}{ Kasem } \\
\hline \multicolumn{13}{|l|}{ Pramoon } \\
\hline \multicolumn{13}{|l|}{ Sompong } \\
\hline Bunchoy & & & & & & & & & & & & \\
\hline
\end{tabular}

The number of remained fronds after thinning differed among farms, which ranged from 2 to 10 fronds (Table 1). The location of sap collection was changed in a farm. Kasem's farm was composed of three blocks (Figure 3) and the areas of blocks 1, 2 and 3 were $6,217 \mathrm{~m}^{2}, 4,289 \mathrm{~m}^{2}$ and 7,875 $\mathrm{m}^{2}$, respectively. At each block, sap was collected for 2 to 3 months. Bamboo containers were mostly allocated in block 3 in June and gradually moved to blocks 1 and 2. Finally, sap was collected only in blocks 1 and 2 in December since block 3 was inundated at that time. 


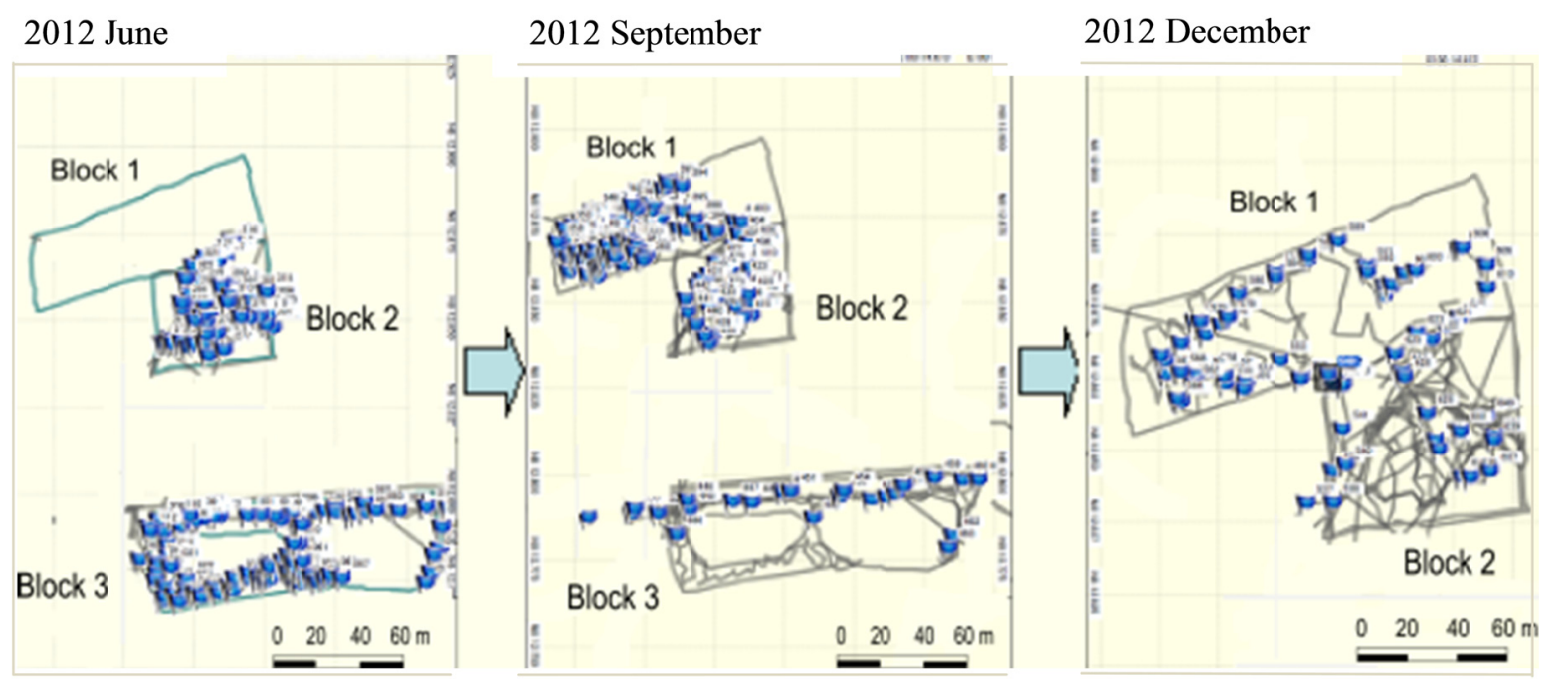

Figure 3. Locations of bamboo containers for collecting sap within a nipa plantation farm indicated by flags. Note that the location sap collection changes according to the season. Farms are divided into three blocks

\subsection{Sap Production}

Sap production differed greatly depending on the farm and year (Table 3). The duration of sap production varied from 20 days (Pramoon's) to 56 days (Kovit's). Over a span of three years, $(2010-2012)$, Kovit's farm showed the highest sap production, recording 78 litres of sap collected from one single fruit stalk in 56 days. In Yong Yot farm, 27 litres of sap was collected invariably in three years. The total sap production was lowest in Pramoon's farm. Mean daily sap production was calculated from total sap production and number of sap collection days. The highest daily sap production was also recorded in Kovit's farm where nearly 1 litre of sap was produced daily from a single fruit stalk in three consecutive years. Daily sap production was significantly different between years in Pakdee's farm.

Sap production was nearly constant in Kasem farm from the start to the end of sap collection (Figure 4) but it decreased gradually in Yong Yot and markedly in Pramoon's farm. Kan farm showed a fluctuation of sap production with a slight increase from the 30th day and a significant decrease after the 55th day. Kovit's farm also showed a fluctuation of sap production, but notably maintained a high sap production of over 1,200 $\mathrm{ml}$ even after 50 days.

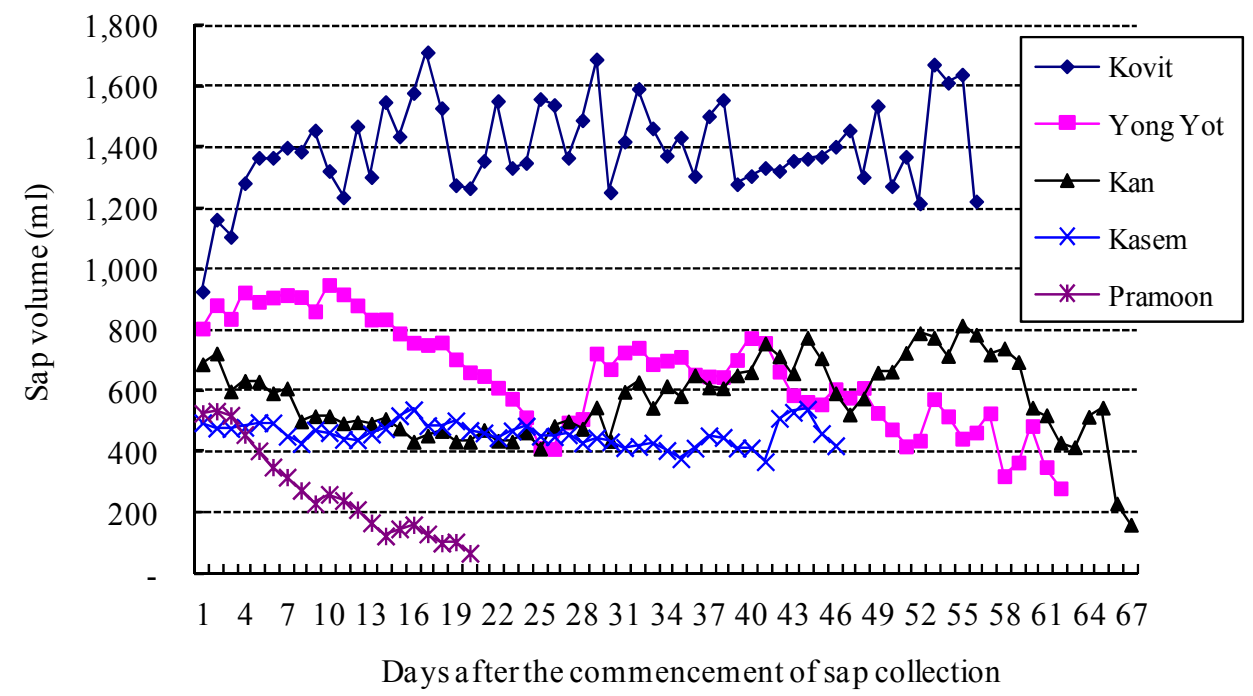

Figure 4. Changes in sap production in five farms. Duration of sap production differed depending on the farm Daily sap production also differed among farms 
Table 3. Sap production from a singe flower stalk in 2010, 2011 and 2012

\begin{tabular}{|c|c|c|c|c|c|c|}
\hline \multirow[b]{2}{*}{ Farm } & \multirow[b]{2}{*}{ Year } & \multirow{2}{*}{$\begin{array}{r}\text { Number of } \\
\text { monitored } \\
\text { stalks } \\
\end{array}$} & & \multicolumn{3}{|c|}{ per a single flower stalk } \\
\hline & & & & $\begin{array}{c}\text { Total sap } \\
\text { production (ml) }\end{array}$ & $\begin{array}{c}\text { Period of sap } \\
\text { collection (days) }\end{array}$ & $\begin{array}{l}\text { Daily sap production } \\
(\mathrm{ml} / \text { day })\end{array}$ \\
\hline \multirow[t]{6}{*}{ Kovit } & 2010 & 7 & Mean & 49,251 & 52.0 & 952.2 \\
\hline & & & $\mathrm{Stdv}^{*}$ & 17,229 & 19 & 24 \\
\hline & 2011 & 6 & Mean & 53,373 & 50.5 & $1,061.1$ \\
\hline & & & Stdv & 26,177 & 20 & 239 \\
\hline & 2012 & 3 & Mean & 78,330 & 56.0 & $1,398.8$ \\
\hline & & & Stdv & 8,573 & 0 & 153 \\
\hline \multirow[t]{4}{*}{ Pakdee } & 2011 & 5 & Mean & 15,536 & 28.0 & 543.5 \\
\hline & & & Stdv & 10,621 & 16 & 101 \\
\hline & 2013 & 3 & Mean & 59,877 & 51.0 & $1,174.1$ \\
\hline & & & Stdv & 1,819 & 0 & 36 \\
\hline \multirow[t]{6}{*}{ Yong Yot } & 2010 & 6 & Mean & 27,565 & 32.8 & 808.8 \\
\hline & & & Stdv & 16,587 & 9 & 272 \\
\hline & 2011 & 3 & Mean & 24,661 & 27.4 & 789.9 \\
\hline & & & Stdv & 13,042 & 10 & 340 \\
\hline & 2012 & 18 & Mean & 27,553 & 37.0 & 749.4 \\
\hline & & & Stdv & 16,267 & 15 & 288 \\
\hline \multirow[t]{4}{*}{ Kan } & 2011 & 11 & Mean & 41,013 & 46.4 & 790.7 \\
\hline & & & Stdv & 35,837 & 16 & 451 \\
\hline & 2012 & 15 & Mean & 23,670 & 41.6 & 531.7 \\
\hline & & & Stdv & 13,952 & 15 & 144 \\
\hline \multirow[t]{2}{*}{ Kasem } & 2012 & 19 & Mean & 13,274 & 26.4 & 496.3 \\
\hline & & & Stdv & 7,159 & 11 & 175 \\
\hline \multirow[t]{2}{*}{ Pramoon } & 2012 & 3 & Mean & 5,317 & 20.0 & 265.8 \\
\hline & & & Stdv & 2,167 & 0 & 108 \\
\hline \multirow[t]{4}{*}{ Sompong } & 2010 & 7 & Mean & 8,042 & 27.0 & 284.1 \\
\hline & & & Stdv & 5,117 & 10 & 107 \\
\hline & 2011 & 3 & Mean & 7,470 & 20.7 & 358.6 \\
\hline & & & Stdv & 2,918 & 4 & 94 \\
\hline
\end{tabular}

Stdv* - standard deviation.

\subsection{Sugar Content in Sap}

The conversion rate of sap to sugar by boiling and evaporation is 100 litres of sap to $21 \mathrm{~kg}$ sugar on average. However, this depends on the sugar content in sap. Figure 5 shows the changes in sugar content in sap in five farms. Kasem's, Kan's, and Yong Yot's farms showed a consistent sugar content during the sap collection period. The sugar content in Kasem farm remained as high as $20 \%$, while $16 \%$ in Yong Yot farm. In Kovit's farm, the sugar content was $18 \%$ at the start of sap collection and decreased to less than $13 \%$ at the end. Regardless of a low sap production, the sugar content was consistently high during the sap collection period in Pramoon's farm. 


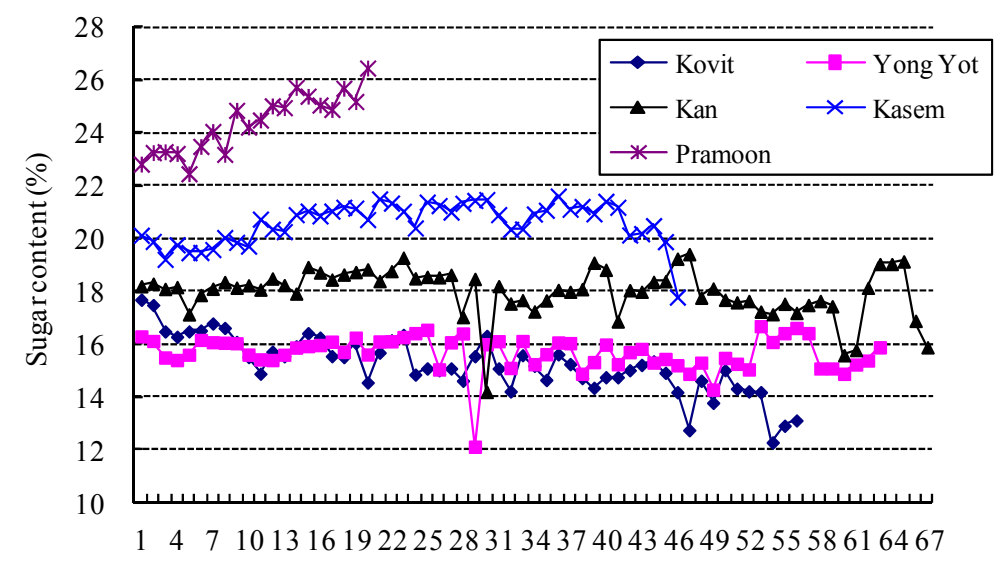

Days a fter the commencement of sap collection

Figure 5. Changes in sap sugar content expressed in Brix (\% w/w). The sugar content in Pramoon's farm significantly increased in 20 days despite the duration of sap collection being low. The sugar contents were approximately $20 \%$ in Kasem's farm and 16\% in Yong Yot's farm

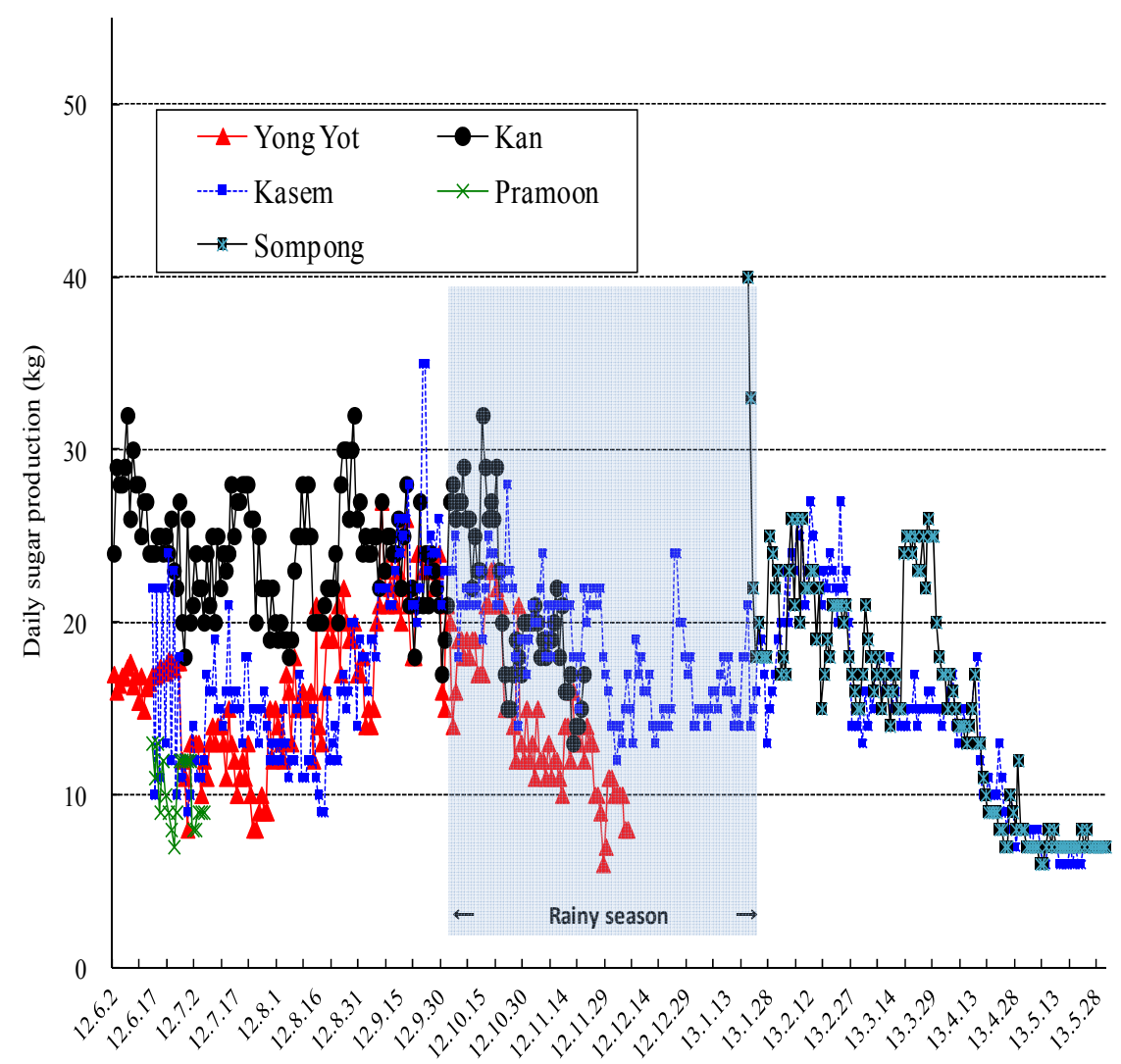

Figure 6. One-year changes in sugar production at different farms from the beginning of June 2012 to the end of May 2013. Sugar production was low during the rainy season (Dec) owing to water inundation and in May owing to the decrease in the number of fruit clusters caused by damage to flower buds during the rainy season

\subsection{Sugar Production}

Sugar production fluctuates in a year (Figure 6). Sugar production tends to decrease in the rainy season. However, sugar can be produced throughout a year, as shown in Kasem farm. The sugar production rates in tons per hectare per year were 6.5 in Kan farm, 6.4 in Pramoon's farm, 4.0 in Yong Yot's farm, 3.3 in Kasem's farm, 
and 3.2 in Sompong's farm. Generally, the sugar content in sap tends to decrease when the volume of sap produced is high, which is expressed as follows:

$$
\text { Sugar content }\left(\text { Brix \% w/w) }=-0.004 x \text { Sap volume }(m l)+20.7\left(R^{2}=0.25\right)\right.
$$

Equation (1) shows that when 1 litre more of sap is produced, sugar content decreases by $4 \%$. In 1,892 measurements, the mean sugar content was $18.1 \%$ and the average daily sap production per fruit stalk was 646.7 $\mathrm{ml}$ (Figure 7). Some relationship between sap production and sugar content was found in Kan's and Pramoon's farms but not in Kasem's farm. Kasem's farm showed an invariable sap production but the sugar content differed markedly from $14-25 \%$, which was in contrast with Pramoon's farm in which the sugar content was in the narrow range between 22 and $27 \%$.
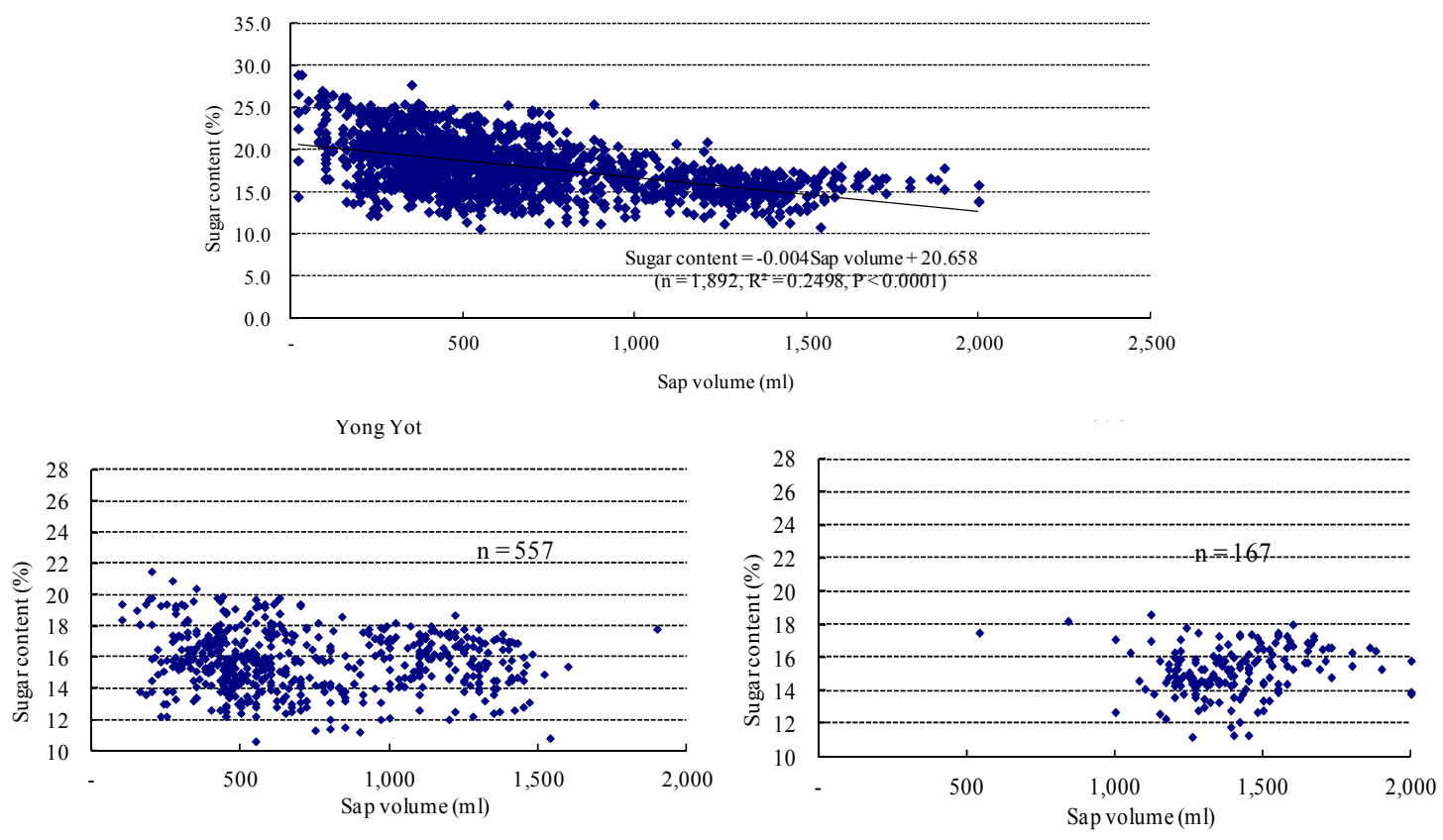

Kan
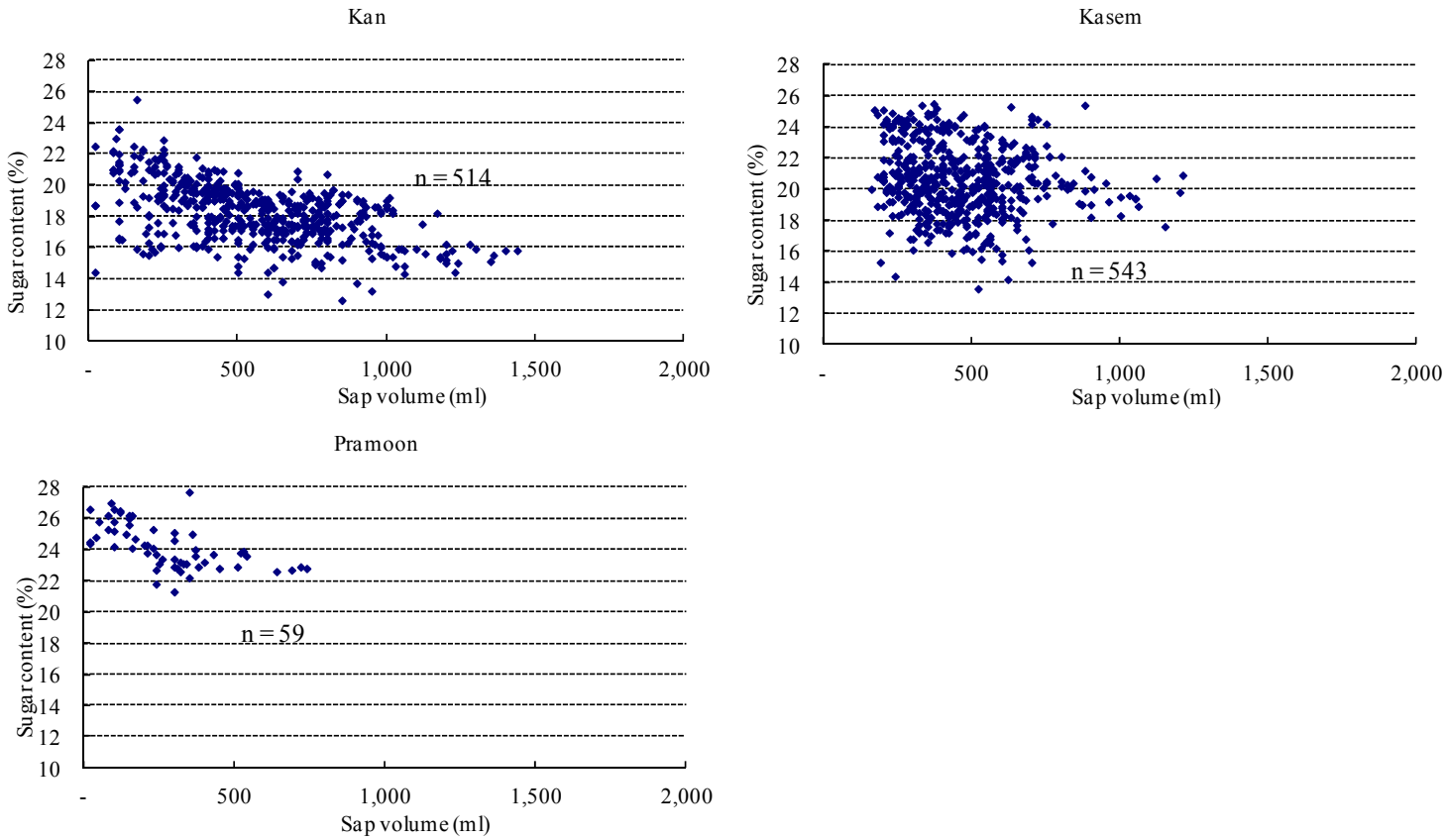

Figure 7. Relationship between sugar content and sap volume. Sugar content generally tends to decrease with increasing sap production $(n=1,892)$, but this relationship was not very clear in some farms. Sap production did not vary in some farms such as Kovit's and Kasem's farms, indicating that sugar content is not a function of sap production 


\subsection{Growth Pattern Of Fruit Stalks}

Figure 8 shows changes in fruit stalk length over 75 days. In 75 days, fruit stalks elongated $25-30 \mathrm{~cm}$ in Kovit's farm, $30-70 \mathrm{~cm}$ in Kan farm and $60-90 \mathrm{~cm}$ in Yong Yot farm. The length of fruit stalks increased over $80 \mathrm{~cm}$ at Kan and Yong Yot farms, whereas their growth was rather slow at Kovit's farm. Because Kovit's farm was frequently inundated by water, water may have affected the growth of fruit stalks.

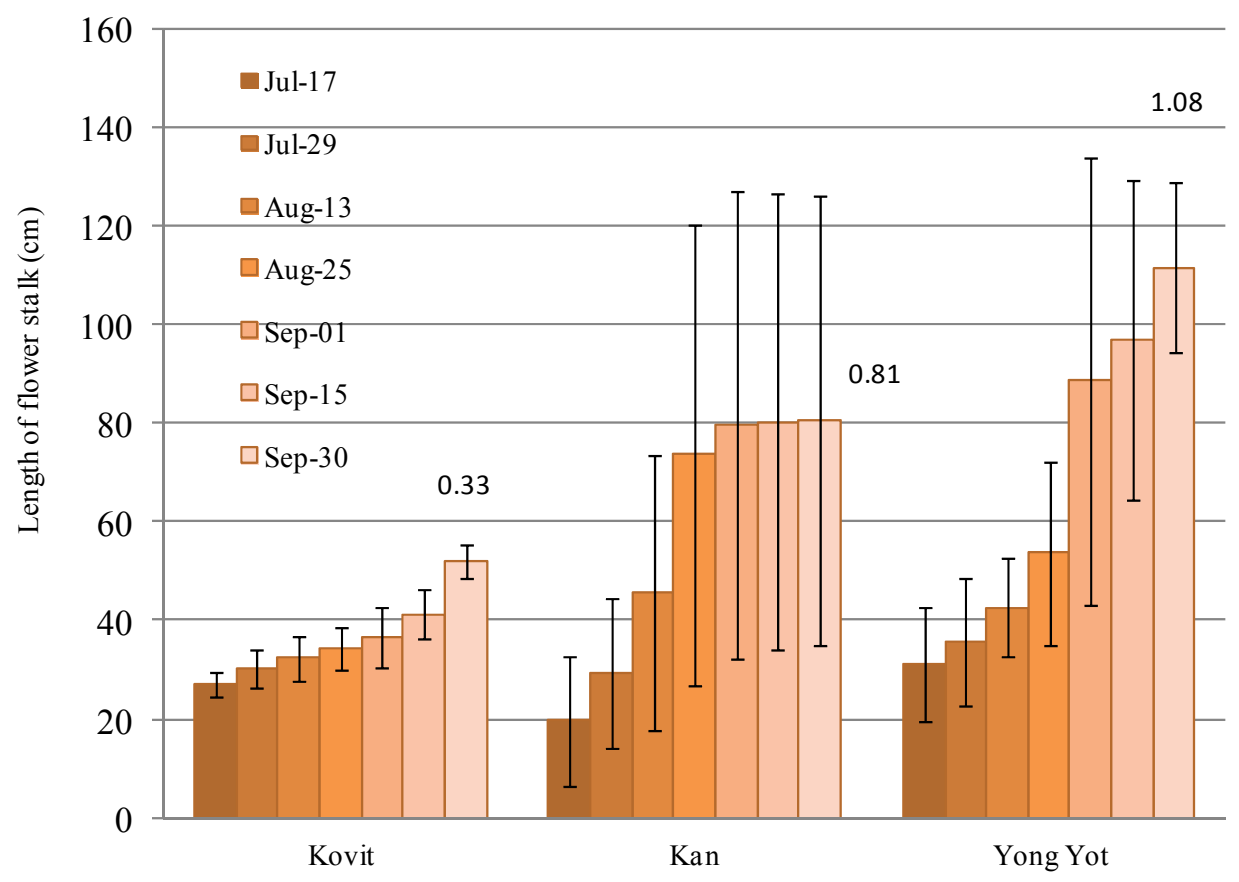

Figure 8. Growth of fruit stalks measured for 75 days from 17 Jul to 30 September 2012 at three farms. Values in the figure show the growth rate $(\mathrm{cm} /$ day) during 75 days. The rate of growth was lower at Kovit's farm possible owing to inundation. Error bars indicate the standard deviation

Both the perimeter and length of fruit stalks were much larger in Kovit's farm than in other farms (Table 4). The number of fronds surrounding a fruit stalk was in the range from 6 to 8, except in Yong Yot farm. SPAD value, which is an indicator of chlorophyll content, was also highest in Kovit's farm, indicating a higher photosynthesis activity in this farm than in the other farms.

Table 4. Biophysical properties of fruit stalks and number of surrounding fronds

\begin{tabular}{lrrrrr}
\hline & \multicolumn{3}{c}{ Fruit stalk } & \multicolumn{2}{c}{ Frond } \\
\cline { 2 - 6 } Farm & $\begin{array}{r}\text { Diameter } \\
(\mathrm{cm})\end{array}$ & $\begin{array}{r}\text { Length } \\
(\mathrm{cm})\end{array}$ & $\begin{array}{r}\text { Height above } \\
\text { ground }(\mathrm{cm})\end{array}$ & $\begin{array}{r}\text { Number of fronds } \\
\text { surrounding fruit stalk }\end{array}$ & $\begin{array}{r}\text { SPAD value } \\
\text { Kovit }\end{array}$ \\
\cline { 2 - 7 } Pakdi & 5.19 & 173.3 & 68 & 8 & 54.9 \\
Yong Yot & 3.25 & 85.3 & 118 & 10 & 49.2 \\
Sompong & 3.73 & 80.3 & 105 & 6 & 46.3 \\
\hline
\end{tabular}

The number of flower buds was smaller in the rainy season (December) than in the dry season (June) (Figure 9) and differed depending on the year. This would indicate the influence of water inundation. The submergence of the nipa plant in water inhibits the emergence of fruit stalks and damages young flower buds. However, because the nipa fruit can stay alive nearly half a year after its maturation, fruit clusters are observed almost throughout the year. 
1) Flower bud

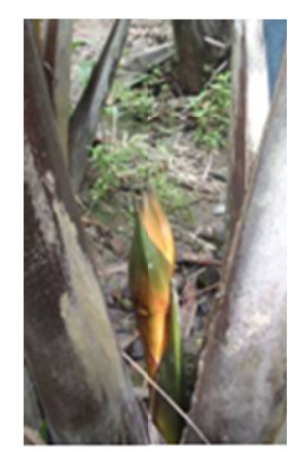

2) Fruit stalk

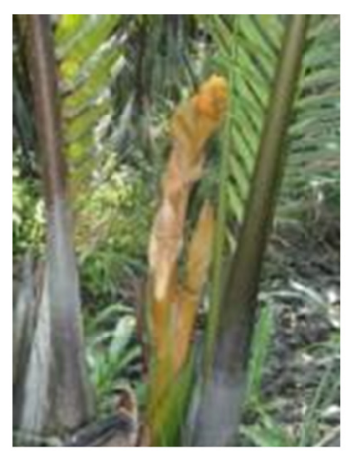

3) Flower and young fruit

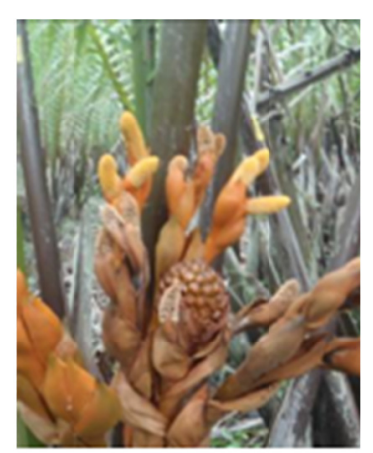

4) Mature fruit

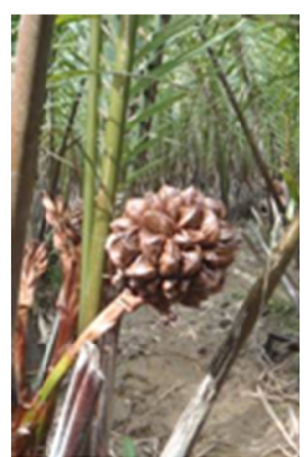

Number
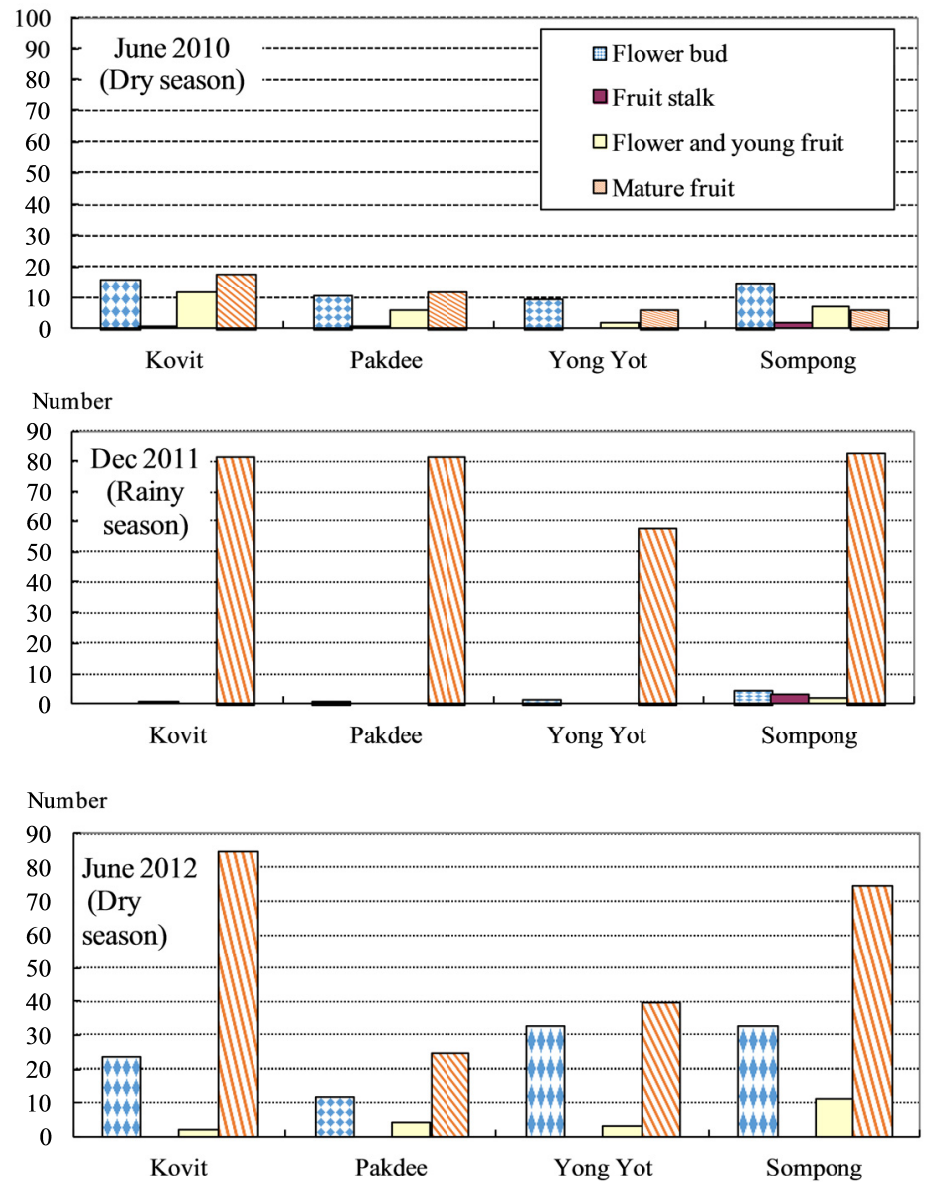

Number

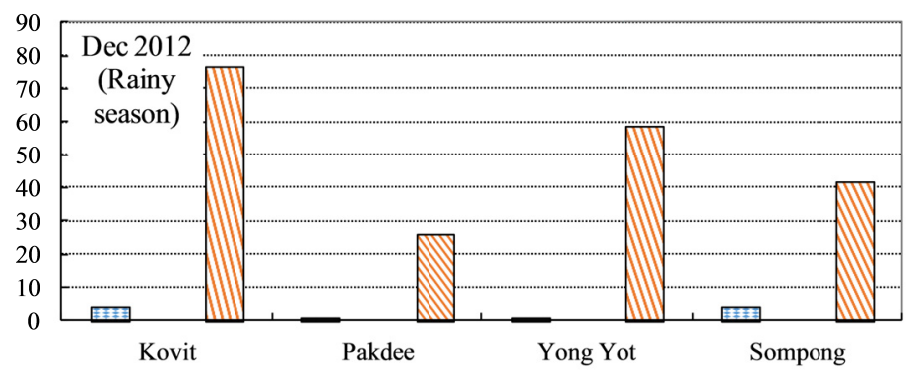

Figure 9. Number of fruit stalks at different growth stages. Few flower buds were observed during the rainy season (December) as an effect of prolonged inundation 
The growth behavior of fruit stalks in the frequent inundated area differed from that in the seldom inundated area (Figure 10). In the case of fruit stalks in the seldom inundated area, 14 days was needed from flower bud emergence to flowering, whereas in the case of those in the frequent inundated area, 20 days was required. The duration from flowering to fruiting was the same in both cases (10 days). The duration from flower bud emergence to fruit maturation for fruit stalks in the seldom inundated area was three months and that for fruit stalks in the frequent inundated area was four months. In both cases, ripe nut detachment occurred one year after fruit bud emergence.

\section{Discussion}

\subsection{Sap/Sugar Production}

Many other palm species can also produce sap, and the duration that a palm tree can be tapped also greatly varies depending on the palm species. Borassus flabellifer and Phoenix sylvestris produce sap only seasonally, and Arenga pinnata and Caryota urens produce sap for $5-7$ years because C. urens flowers every two or three years (Redhead, 1989; Dissanayake, 1977). Elaeis guineensis and Cocos nucifera produce sap for a much longer period: 10 to 15 years for E. guineensis and 20 years for C. nucifera (Abedin et al., 1987). Coconut palms can be tapped throughout the year as long as rainfall is satisfactory and every palm is allowed to rest for 4 months a year (Coconut Research Institute, 1967). Nevertheless, the duration and number of months of nipa sap collection vary among the farms (Table 2). When a farm is large enough, sap can be tapped throughout the year by changing the location of collection (Figure 3). Moreover, a large enough farm can solve the problem of damage caused by prolonged inundation.

The estimates of daily sap yield considerably varied from 0.02 to 2 litres per fruit stalk. The same was true for the sugar content of the sap (from 12 to $26 \%$; Figure 5). A high variation in sap yield was observed among fruit stalks in the same farm but the variation among years in the same farm was relatively small except for Pakdee's farm (Table 3). This indicates that sap productivity is controlled by land quality.

The age of farm, palm density and climatic conditions are the factors controlling maple sugar content (Taylor, 1956). Our study was conducted under the same climatic conditions. Age and density do not likely markedly affect sugar content, indicating that there are other factors controlling the sugar content of sap. Frond length decreased in the order of Kovit's $(684.8 \mathrm{~cm})$, Yong Yot's $(646.7 \mathrm{~cm})$, Bumchay's $(602.9 \mathrm{~cm})$ and Sompong's $(540.3 \mathrm{~cm})$ farms; sap production also followed this order. The diameter of fronds also showed the same tendency; the larger the diameter, more sap was produced. Biomass is a function of frond length and diameter; therefore, frond biomass could be related to the productivity of sap production.

Sugar is produced at the rates of 5-15 tons/ha/year for sugarcane, 18 tons/ha/year for Borassus flabellifer under rain-fed conditions (Khieu \& Preston, 1995; Khieu, 1996) and 19 tons/ha/year for the coconut tree (Jeganathan, 1974). In this study, it was estimated that nipa farming produces sugar at rates of 3.2 to 6.5 tons/ha/year, which is comparatively low. However, sugar production from nipa sap has advantages as follows: 1) no labor seasonality, 2) no replanting and rotation, 3) no residues and 4) not competitive with other crops (Hamilton \& Murphy, 1988).

The sugar content of nipa sap was reported to be $16.4 \%$ in Papua New Guinea (Päivöke, 1983), whereas our study showed a higher content of $18.1 \%$. The reason for this is not yet clearly known, other than the effect the volume of sap produced (Figure 7). The maple sugar content is affected by light, altitude, temperature, soil and water condition (Taylor, 1956). In the case of nipa, temperature, soil and water condition are considered to be most probable factors affecting sugar content.

\subsection{Growth Behavior of Fruit Stalks}

Growth behavior and the time of flowering and fruiting of plants are generally unclear in humid tropics because the dry and wet seasons are not distinctly divided. Our study site is located in monsoon tropics with clear difference between two seasons (Figure 2); thus, we expected that plant growth behavior may demonstrate seasonality. The growth behavior of nipa fruit stalks in this study site seems to be influenced by seasonality; flowering and fruiting were observed throughout the year, but flower buds were scarecely found during a prolonged inundation period. Similarly to Borassus flabellifer that shows reduced sap yield during prolonged flooding (Dalibard, 1999), our study also showed that inundation affected the growth of fruit stalks (Figure 9) and decreased sugar production during the rainy season (Figure 6). Fruit stalk growth was also different between fruit stalks in the frequent inundated area and those in the seldom inundated area (Figure 10). These indicate that the growth of fruit stalks is regulated by water, suggesting that it is vital to find adequate water condition for fruit stalk growth and for a higher sap/sugar production. 
Frequent inundated area

(29 June 2012)

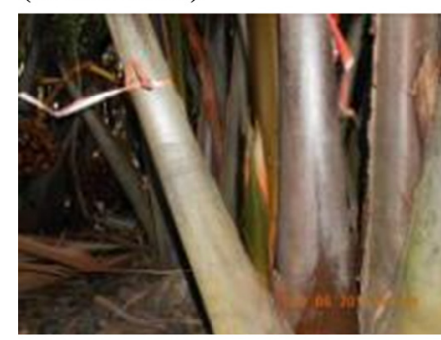

(20 July 2012)

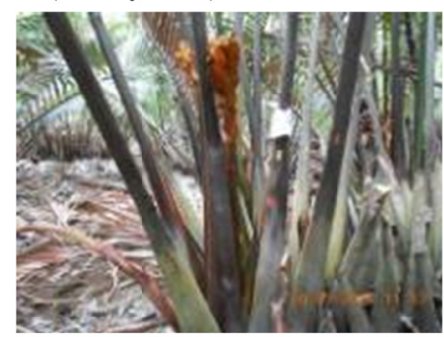

(11 Nov 2012)

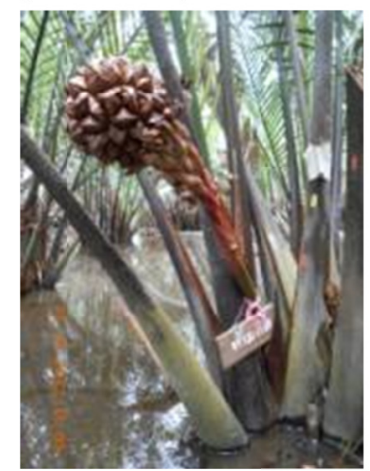

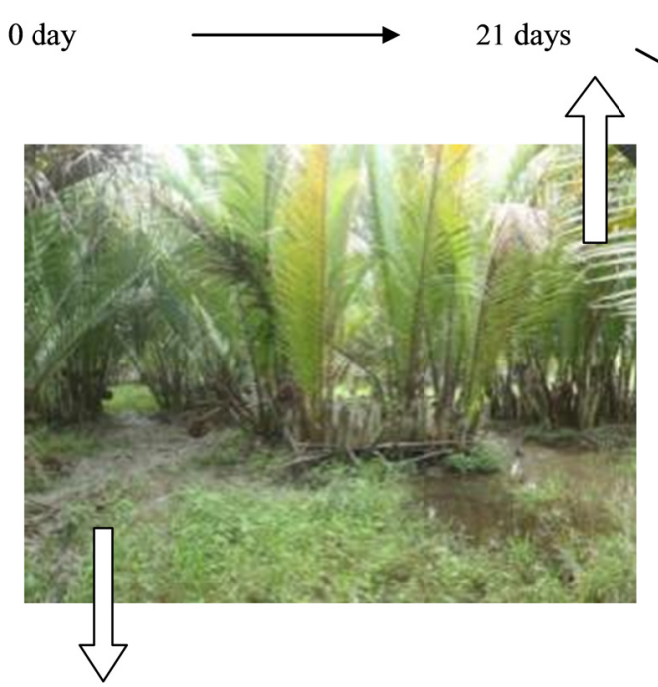

.

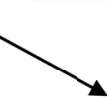

135 days

Seldom inundated area

(12 Sep 2012)

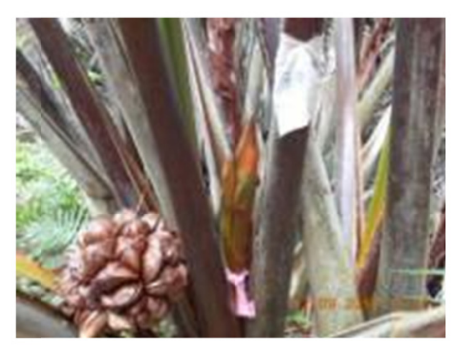

0 day
(28 Sep 2012)

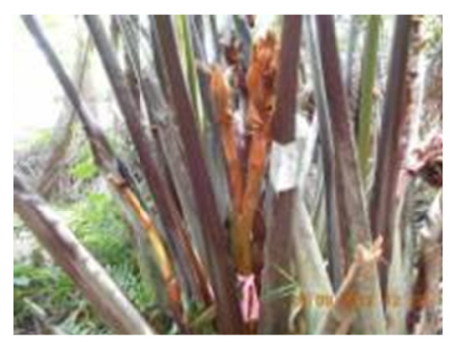

16 days
(20 Jan 2013)

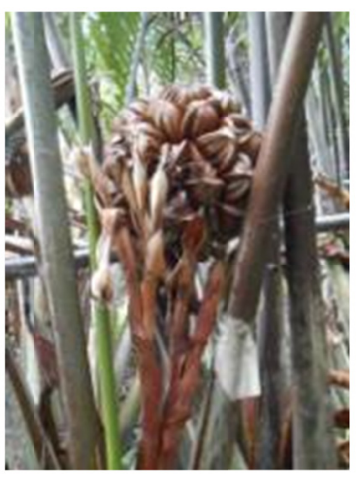

130 days

Figure 10. Stages of fruit stalk development in Kovit's farm at the areas under a high and low influence of the water. Flowering started 16 days after flower bud emergence at the seldom inundated area, which was 5 days earlier than at the frequent inundated area. The total number of days till the maturity of fruit was 135 days at the frequent inundated area and 130 days at the seldom inundated area. The central picture shows the cluster of fronds

\subsection{Farm Management}

Mature fronds of nipa are removed as materials for thatch or fuel, which is considered to affect sap yield (Kiew 1989). Dalibard (1999) also stated that nipa produces more sap when stands are kept thinned by removing old stalks. With more fronds, photosynthetic activity increases, resulting in higher sap production; however, more energy is consumed owing to an increased respiration rate. The number of fronds remaining after thinning differed among the farmers (Table 1), which did not show a close association with sap production. It is not the number of fronds, but the growth properties of fronds and fruit stalks more likely affect sap yield. Larger and 
longer fruit stalks were associated with higher sap production (Table 4), which coincided with the results reported by Rasco Jr. et al. (2012), that is, the number of sap production days and fruit stalk length highly correlate with sap yield.

In Pamplona and Cagayan, Philippines, 1 ha is considered to be an economically viable land size for nipa sap farming (Ame et al., 2011). This obviously depends on the family size and economic condition. Our study however showed that the economically viable size for nipa farming in southern Thailand was lower than this, $0.5-0.75 \mathrm{ha} /$ person.

The location of sap collection was changed every two or three months (Figure 3). This cannot be done in small farms such as Pramoon's farm. Moving the tapping location may prevent the overexploitation of nipa plants and provide some time for the plants to recover, improving land productivity.

\subsection{Longevity of Nipa Farming}

One notable characteristic of nipa farming is its long-term operation. In the study area, nipa farming has been operated over 100 years, during which sap has been continuously collected without replanting and fertilization (a few farmers applied fertilizer). This outstanding longevity enables sustainable land use in tropical coastal areas, which is in sharp contrast to short-lived land use (5 years on average) in an intensive shrimp aquaculture (Sathirathai, 1998). Many coastal areas are likely to benefit from nipa farming when it is well combined with other land uses.

On the basis of a successful system of long-term and well-managed mangrove charcoal production and fishery, Matsui (2010) pointed out a stable income from mangrove products is necessary for sustainable mangrove management, provided that productivity is securely maintained. Nipa farming provides a stable income with sustained productivity; therefore, it could play a key role in sustainable coastal management.

\section{Conclusions}

The duration of sap collection, sap yield and sugar content were highly variable among fruit stalks and farms. The duration of sap production from the same fruit stalk was from 20 days to 56 days with the daily sap yield ranging from 0.02 to 2 litres and with the sugar content from 10.6 to $28.6 \%$. Sugar content significantly differed among farms, although the daily variation in the same fruit stalk was small. The length and diameter of fruit stalks were related with sap production. Higher sap production was found in the thicker and longer the fruit stalks. Both the number and the growth of fruit stalks were influenced by water inundation because fruit maturation was retared as well by submergence of water. These imply that hydraulic management would be an important measure to enhance nipa sap production.

\section{Acknowledgements}

The research was fully funded by Kansai Electric Power Co., Inc., Japan. We would like to thank Mr. Yutakarn for collecting sap in the field. We also thanks all the nipa farm owners, Messrs. Kovit, Pakdee, Yong Yot, Kan, Kasem, Pramoon, and Sompong, for giving us the opportunity to conduct research in their farms.

\section{References}

Abedin, Z., Aktar, S., Haque, F., \& Alam, S. (1987). Uses of Multipurpose Trees on the Small Farms of the Low-Rainfall Ganges Floodplain Soils of Bangladesh. Proceedings of an international workshop held in Pataya, Thailand (pp. 31-47).

Alongi, D. M. (2002). Present state and future of the world's mangrove forests. Environmental Conservation, 29(3), 331-349. http://dx.doi.org/10.1017/S0376892902000231

Ame, R. B., Ame, E. C., \& Ayson, J. P. (2011). Management of the nypa mangrove as a mitigating measure against resource over-utilization in Pamplona, Cagayan. Kuroshio Science, 5(1), 77-85.

Bamroongrugsa, N., \& Purintavarakul, C. (2006). Growing nipa palm for restoration of abandoned shrimp ponds. Wetland Science, 4(2), 91-95.

Bamroongrugsa, N., Buachum, S., \& Purintavarakul, C. (2008). Nipa Palm (Nypa fruticans Wurmb) cultivation in salt affected paddy fields. J.of Tropical Plants Research, 1, 93-102.

Bamroongrugsa, N., Purintavarakul, C., Kato, S., \& Stargardt, J. (2004). Production of Sugar-Beating Sap from Nipa Palm in Pak Phanang Basin, Southern Thailand. Bulletin of the Society of Sea Water Science, Japan, 58(3), 304-312.

Coconut Research Institute. (1967). Toddy tapping, Ceylon. Leaflet No. 48. P 13 
Dalibard, C. (1999). Overall view on the tradition of tapping palm trees and prospects for animal production. Livestock Research for Rural Development, 11(1). http://Irrd.cipav.org.co/Irrd11/1/dali111.htm

Dissanayake, B. E. (1977). Use of Caryota urens in Sri Lanka. In K. Tan (Ed.), First International Sago Symposium. The Equatorial Swamp as a Natural Resource (pp 84-90). East Malaysia, Kuching 1976 Kuala Lumpur.

Dransfield, J. (1977). Dryland Sago Palms. Sarawak, East Malaysia, Kuching. In K. Tan (Ed.), The Equatorial Swamp as a Natural Resource: Proceedings of the First International Sago Symposium (pp 76-83). Kuala Lumpur.

Fox, J. F. (1977). Harvest of the Palm, Ecological Change in Eastern Indonesia. Harvard University Press, Cambridge, Massachusets, and London, England, p 290

Hamilton, L. S., \& Murphy, D. H. (1988). Use and management of nipa palm (Nipa fruticans, Arecaceae): a review. Economic Botany, 42(2), 206-213. http://link.springer.com/article/10.1007\%2FBF02858921

Jeganathan, M. (1974). Toddy yields from hybrid coconut palms. Ceylon Coconut Quarterly, 25, 139-148.

Khieu, B. (1996). A study on the use of the sugar palm tree (Borassus flabellifer) for different purposes in Cambodia (master's thesis) Swedish University of Agricultural Sciences, Uppsala, Sweden.

Khieu, B., \& Preston, T. R. (1995). Conserving biodiversity and the environment and improving the wellbeing of poor farmers in Cambodia by promoting pig feeding systems using the juice of the sugar palm tree (Borassus flabellifer). Livestock Research for Rural Development, 7(2), 25-29.

Kiew, R. (1989). Utilization of Palms in Peninsular Malaysia. Malayan Naturalist, 43(1\&2), 43-67.

Matsui, N. (2010). Mangrove management and community participation in Thailand. In: R. Show, \& R. R. Krishnamurthy (Eds.), Communities and coastal zone management (pp 295-307), Research Publishing Services.

Matsui, N., Bamroongrugsa, N., Morimune, K., Miyasaka, H., \& Okimori, Y. (2011). Nipa palm: A potential alternative source for bioethanol. Research Paper 14th Mangrove National Seminar [Thai], 319-324.

Päivöke, A. E. A. (1983). Nipa palm (Nipa fruticans) as a raw material. Abstracts on Tropical Agriculture, 9(9), 11-19.

Päivöke, A. E. A. (1985). Tapping practices and sap yields of the nipa palm (Nipa fruticans) in Papua New Guinea. Agriculture, ecosystems \& environment, 13(1), 59-72.

Rasco, Jr. E. T., Ragas, R. G., \& Junio, R. G. (2012). Morphological and sap yield variation in Nipa (Nypa fruticans Wurmb.). Asia Life Sciences, 21(1), 123-132.

Redhead, J. (1989). Utilization of tropical foods: trees. In FAO Food and Nutrition Paper No 47: 3. FAO, Rome.

Sathirathai, S. (1998). Economic valuation of mangroves and the roles of local communities in the conservation of natural resources: Case study of Surat Thani, South of Thailand. EEPSEA Research Report Series. Singapore: Economy and Environment Program for Southeast Asia.

Tamunaidu, P., Matsui, N., Okimori, Y., \& Saka, S. (2013). Nipa (Nipa fruticans) sap as a potential feedstock for ethanol production. Biomass and Bioenergy, 52, 96-102. http://hdl.handle.net/2433/174338

Tayler, F. H. (1956). Variation of sugar content of maple sap. Agricultural experiment station, University of Vermont and State Agricultural College Burlington, Vermont, Bulletin 587, p 39

Tsuji, K., Ghazalli, M. N. F., Nordin, Z., Khaidizar, M. I., Dulloo, M. E., \& Sebastian, L. S. (2011). Biological and Ethnobotanical Characteristics of Nipa Palm (Nipa fructicans Wurmb.): A Review. Sains Malaysiana, 40(12), 1407-1412.

Udofia, S. I., \& Udo, E. S. (2005). Local knowledge of utilization of Nipa Palm (Nipa Fruticans, Wurmb) in the coastal areas of Akwa Ibom state, Nigeria. Global Journal of Agricultural Sciences, 4(1), 33-40. http://dx.doi.org/10.4314/gjass.v4i1.2252

\section{Copyrights}

Copyright for this article is retained by the author(s), with first publication rights granted to the journal.

This is an open-access article distributed under the terms and conditions of the Creative Commons Attribution license (http://creativecommons.org/licenses/by/3.0/). 